\title{
К ВОПРОСУ О ПОРЯДКЕ ГОЛОСОВАНИЯ ЗАКОНОДАТЕЛЬНЫМ (ПРЕДСТАВИТЕЛЬНЫМ) ОРГАНОМ ГОСУДАРСТВЕННОЙ ВЛАСТИ СУБЪЕКТА РОССИЙСКОЙ ФЕДЕРАЦИИ ПРИ ПРИНЯТИИ НОРМАТИВНЫХ ПРАВОВЫХ АКТОВ
}

\section{TO THE QUESTION OF THE VOTING PROCEDURE WHEN THE LEGISLATIVE (REPRESENTATIVE) BODY OF STATE POWER OF A SUBJECT OF THE RUSSIAN FEDERATION ADOPTS REGULATORY LEGAL ACTS}

V. Grunina M. Bachernikhina

Summary: The article discusses the problematic issues of the procedure for adopting laws at the level of the constituent entities of the Russian Federation. The article analyzes the problems associated with the voting procedure when the legislative (representative) body of state power of the constituent entity of the Russian Federation adopts regulatory legal acts.

Keywords: legislative process, rule-making, law, voting, legal norms.

\author{
Грунина Вероника Александровна \\ К.ю.н., дочент, Владимирский филиал РАНХ и ГС \\ при Президенте РФ \\ vgrun@rambler.ru \\ Бачернихина Мария Викторовна \\ К.ю.н., старший преподаватель, Владимирский \\ юридический институт ФСИН Россииария \\ mamchun1982@yandex.ru
}

Аннотация: В статье рассматривается проблемные вопросы процедуры принятия законов на уровне субъектов РФ. Анализируются проблемы, связанные с порядком голосования при принятии законодательным (представительным) органом государственной власти субъекта Российской Федерации нормативных правовых актов.

Ключевые слова: законотворческий процесс, нормотворчество, закон, голосование, правовые нормы.
$\mathrm{B}$ законодательном процессе субъектов РФ можно выделить следующие основные стадии: законодательная инициатива, обсуждение законопроекта, принятие закона, подписание и обнародование закона, и дополнительную стадию - экспертиза проекта закона, осуществляемая непосредственно региональными парламентами или иными органами власти [1].

Итак, законотворческий процесс включает в себя стадию принятия закона. Принятие закона возможно путем голосования. В самом общем смысле голосование представляет собой подачу голосов при коллективном решении какого-либо вопроса. Исходя из рассматриваемой темы, ставится вопрос об одобрении или отклонении проекта нормативного правового акта по тем или иным причинам.

По нашему мнению, без честного и объективного голосования невозможно достичь тех целей, которые стоят перед региональным законодателем, а именно: развитие субъекта РФ, принимая во внимание объективные и субъективные факторы. К объективным факторам следует отнести реально существующие в момент обсуждения законопроекта общественные отношения. К субъектив- ным факторам - правосознание, менталитет народа и настроения, существующие в обществе, а также мнение авторитетных ученых-юристов, экспертов, практиков и мнение самих законодателей.

Голосование является важной формой выражения воли законодательного (представительного) органа субъекта РФ, а значит, и выражения воли всего населения региона по поднимаемому законопроектом вопросу. Именно голосование в конечном итоге решает судьбу законопроекта. При голосовании качественные характеристики рассматриваемого законопроекта подтверждаются количественными, т.е. числом лиц, проголосовавших за его принятие.

Следует отметить, что процесс голосования можно рассматривать с точки зрения факторного подхода. Факторы, влияющие на исход голосования, весьма разнообразны. Объективность и превалирующие позиции умов не всегда находят свое выражение в реальных результатах голосования. Однако, это в основном практические проблемы организации нормотворческого процесса в субъектах РФ и реализации правовых норм, нежели дискуссионный вопрос в науке. 
Отрицательный опыт внесения законопроекта и неудачи при голосовании - это тоже показатель. Он связан с ускорением предыдущих стадий законотворческой деятельности, однако страдает качество нормативных актов. Не следует забывать, что в отдельных случаях, когда затрагиваются острые общесоциальные вопросы региона, то необходимо проведение референдума по обсуждению проектов на региональном уровне [2].

Проведение референдума, хотя такой порядок и предусмотрен законодательно и находит свое отражение в региональных нормативно-правовых актах, весьма затруднителен на практике, поскольку требует большого привлечения ресурсов: материально-финансовой базы, кадровых ресурсов, временных затрат и прочее.

Вернемся непосредственно к организации голосования. Основу рассматриваемого вопроса составляет ст. 7 Закона № 184-Ф3. Данная статья посвящена порядку принятия региональными парламентами нормативных правовых актов различных видов: конституций, уставов субъектов РФ и поправок к ним, законов, постановлений в рамках осуществляемого ими регионального нормотворческого процесса.

Пункты 1-3 ст. 7 указанного федерального закона регламентируют общие требования, предъявляемые по поводу кворума депутатского состава для принятия нормативных правовых актов соответствующего вида. Закрепление на федеральном уровне необходимого кворума голосов, по нашему мнению, неслучайно, поскольку голосование является этапом, решающим дальнейшую судьбу законопроекта. Именно в результате голосования определяется, будет ли жить данный круг правовых норм или нет.

Конституция (устав) субъекта Российской Федерации, а также поправки к ним принимаются большинством не менее двух третей голосов от установленного числа депутатов. Принятие решение квалифицированным большинством голосов свидетельствует об особой важности для жизни региона данного нормативно-правового акта. Заметим, что на региональном уровне, в отличие от федерального, исключается применение квалифицированного большинства голосов в три четверти. На наш взгляд, это сужает свободу на усмотрение регионального законодателя, поскольку разрешение тех или иных законотворческих вопросов с учетом особенностей субъекта РФ может радикальным образом сказаться на дальнейшей судьбе развития соответствующего региона.

Этот императивно установленный кворум является минимально возможным для принятия конституции и устава (субъект РФ вправе установить и иное требование в сторону увеличения соотношения голосов от установленного числа депутатов, необходимое для принятия конституции и устава). Анализ законодательства субъектов Центрального федерального округа показывает, что увеличения соотношения голосов не происходит.

Считаем, что региональное нормотворчество имеет тенденцию к унификации и непоколебимое следование постулатам, которые установлены на федеральном уровне. Это имеет свои положительные и отрицательные стороны. Начнем с положительного: гармонизация и унификация законодательства позволяет создать единое правовое поле по всей стране, приблизить положения, существующие в различных субъектах РФ. В то же время, сведение организации нормотворческого процесса во всех субъектах Российской Федерации к единым строгим рамкам не позволяет учитывать особенности территории, менталитета и специфики тех общественных отношений, которые складываются в отдельных регионах. Сложно найти золотую середину, но федеральный и региональный законодатель, несомненно, должны к этому стремиться.

Таким образом, особое место конституций (уставов) субъектов Российской Федерации в иерархии нормативно-правовых актов субъектов федерации определяет объективная необходимость строгих требований к их принятию и внесению поправок в соответствующие нормативные правовые акты. Отсутствует возможность уменьшения кворума голосов на региональном уровне. Такие особенные процедурные требования являются своеобразной гарантией стабильности всей системы нормативных правовых актов (в том числе, и правовых актов регионального уровня).

Законы субъекта РФ принимаются большинством голосов от установленного числа парламентариев, если иное не предусмотрено законом (речь идет о законе № 184-Ф3). Так, согласно ч. 3 ст. 8 указанного закона, если на стадии обнародования высшее должностное лицо субъекта РФ решит отклонить одобренный депутатами закон, то он (закон) впоследствии может быть одобрен в ранее принятой редакции большинством не менее двух третей голосов от установленного числа депутатов, т.е. в данном случае требуется квалифицированное большинство для преодоления вето должностного лица субъекта Федерации. Во избежание ошибок и с целью окончательной оценки законопроекта, взглянуть на него под другим углом зрения, взвесить все за и против, существует особый институт - право вето. Квалифицированное большинство голосов свидетельствует об особой важности и осознанности такого важного шага, как преодоление вето должностного лица субъекта РФ.

Постановления законодательного (представительного) органа государственной власти субъекта федерации принимаются большинством голосов от числа избранных депутатов, если иное не предусмотрено законом. 
Ранее упоминалась формулировку «установленное число депутатов». Под «установленным числом» подразумевается число депутатов, установленное соответственно конституцией или уставом субъекта Российской Федерации [3]. Количество депутатов индивидуально в каждом субъекте РФ. В основном такое число определяется исходя из численности населения соответствующего субъекта РФ. Так, например, во Владимирской области число депутатов Законодательного Собрания определяется в зависимости от численности избирателей, зарегистрированных на территории Владимирской области, и составляет 38 депутатов (ч.2. ст. 10 Устава Владимирской области [4]).

Установленное число депутатов можно определить как количество доверенных лиц, которым население данного субъекта федерации делегировало свои полномочия для определения основных направлений развития субъекта РФ, принятия наиболее важных решений в сфере нормотворческой деятельности. Депутатский корпус неразрывно связан с населением, и вся его деятельность должна быть направлена на обеспечение истинных интересов населения, повышение общего уровня благосостояния народа.

Важно отметить, что использованная в п.1 и п.2 ст. 7 закона № 184-Ф3 формулировка «установленное число депутатов» не является синонимом «числа избранных депутатов». Согласно п.3 ст. 7 при помощи большинства от числа избранных депутатов принимаются по общему правилу парламентские постановления на региональном уровне.

Отождествление понятий «общее число депутатов» и «число фактически избранных депутатов» не может гарантировать народное представительство в законодательном (представительном) органе государственной власти субъекта Российской Федерации. Поэтому положение об общем числе депутатов следует понимать, как число депутатов, установленное для соответствующего законодательного (представительного) орган государственной власти субъекта РФ.

Пунктом 5 ст. 7 вышеуказанного закона 184-Ф3 также регламентирован общий порядок принятия законов двухпалатными региональными парламентами. Подавляющее большинство парламентов субъектов Российской Федерации - однопалатные, в отличие от федерального парламента. По нашему мнению, на уровне субъектов РФ существование двухпалатных парламентов является излишним, поскольку имеется и должна работать хорошая система фильтрования законопроектов на стадии их подготовки и предварительного рассмотрения. Двухпалатный парламент, с точки зрения организации нормотворческого процесса в субъектах федерации, усложняет процесс нормотворчества и создается большое количество бюрократических проволочек.

Если всё же конституцией (уставом) субъекта РФ предусмотрена необходимость одобрения принятого одной из палат закона другой палатой, то такой закон считается одобренным, если за него проголосовало более половины от установленного числа членов этой палаты. В случае отклонения принятого закона уполномоченной палатой парламента отклоненный закон считается принятым, если при повторном голосовании за него проголосовало не менее двух третей от общего числа депутатов принявшей его палаты.

Этот порядок воспроизводит по аналогии, установленные на федеральном уровне положения Конституции Российской Федерации. Так, согласно Конституции РФ Федеральный закон считается одобренным Советом Федерации, если за него проголосовало более половины от общего числа членов этой палаты, либо если в течение четырнадцати дней он не был рассмотрен Советом Федерации.

В случае несогласия Государственной Думы с решением Совета Федерации федеральный закон считается принятым, если при повторном голосовании за него проголосовало не менее двух третей от общего числа депутатов Государственной Думы (ч.4, 5 ст.105 Конституции РФ). Передача законов, принятых Государственной Думой, на рассмотрение Совета Федерации призвано обеспечить учет его мнения в законодательном процессе и предоставляет ему возможность выразить свое согласие либо несогласие с Государственной Думой в отношении любого закона[5] (что является справедливым и в отношении региональных парламентов с двухпалатной структурой).

Как следует из анализа регионального законодательства, при наличии альтернативных законопроектов (схожих законопроектов по одному и тому же вопросу) проводится рейтинговое голосование. Судьба альтернативных законопроектов решается по итогам рассмотрения на первом чтении.

Если по итогам рейтингового голосования несколько законопроектов набрали достаточное для их принятия число голосов, то принятым в первом чтении считается законопроект, набравший наибольшее число голосов. Если по итогам рейтингового голосования ни один из законопроектов не набрал достаточного для принятия числа голосов, то на голосование о принятии в первом чтении ставится законопроект, получивший наибольшее число голосов.

В заключение хотелось бы отметить, что голосование является важной формой выражения воли законодательного (представительного) органа субъекта РФ, а значит, 
и выражения воли всего населения региона на поднимаемый законопроектом вопрос. Именно голосование в конечном итоге решает судьбу законопроекта. При голосовании качественные характеристики рассматриваемого законопроекта подтверждаются количественными характеристиками, т.е. числом лиц, проголосовавших за его принятие. По нашему мнению, серьезным упущением законодателя является отсутствие регулирования применения инновационных систем в процессе голосования. Практически во всех регионах голосование проводится посредством использования электронной системы, что значительно упрощает процесс голосования.

\section{ЛИТЕРАТУРА}

1. Артамонов А.Н. Создание законов в субъектах Российской Федерации: монография. Ростов-на-Дону. РЮИ РПА Минюста России. 2011. С. 54.

2. Андреева Л.А. Нормотворчество: проблемы и перспективы // Вопросы современной юриспруденции. 2013. № 28. С. 76.

3. Воробьев Н.И., Субанова Н.В. Комментарий к Федеральному закону от 6 октября 1999 г. N 184-Ф3 «0б общих принципах организации законодательных (представительных) и исполнительных органов государственной власти субъектов Российской Федерации», 2015 г. // СПС «ГАРАНТ»

4. Устав (Основной закон) Владимирской области от 14 августа 2001 г.

5. N $62-03 / /$ СПС «ГАРАНТ

6. Постановление Конституционного Суда РФ от 23 марта 1995 г. N 1-П «По делу о толковании части 4 статьи 105 и статьи 106 Конституции Российской Федерации» // СЗ РФ от 27 марта 1995 г., N 13, ст. 1207

○ Грунина Вероника Александровна (vgrun@rambler.ru), Бачернихина Мария Викторовна (mamchun1982@yandex.ru). Журнал «Современная наука: актуальные проблемы теории и практики»

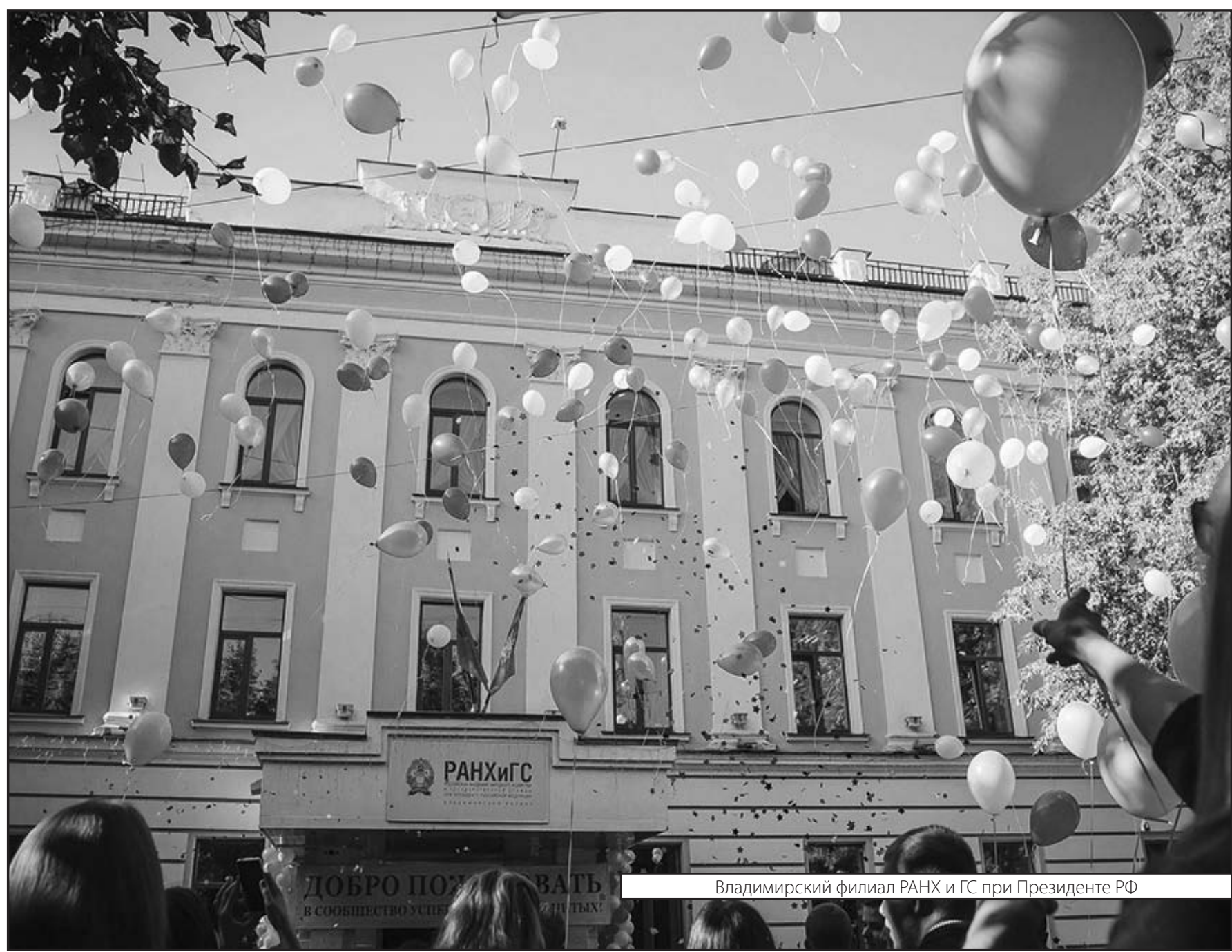

